Павліковський А. К. канд. військ. наук, доцент

(0000-0002-0637-368X);

Іващенко А. М. канд. техн. наук, доцент

(0000-0002-8131-5463);

Возняк С. М., канд. техн. наук, ст. наук. співроб.

(0000-0002-9015-813X)

Центр воєнно-стратегічних досліджень Національного університету оборони України імені Івана Черняховського, Київ

\title{
Особливості оперативного планування багатонаціональним штабом Об'сднаних сил НАТО міжнародних операцій з підтримання миру і безпеки
}

Резюме. Розглядаються зміни у системі оперативного планування НАТО, введені після самітів Північноатлантичного Альянсу 2010 - 2018 рр., етапи планування, завдання та оперативні документи, які розробляються

Ключові слова: НАТО; штаб Об’єднаних сил; оперативне планування; етапи; завдання.

Постановка проблеми. Трансформація Північноатлантичного Альянсу, розширення його функцій і відповідальності у сфері міжнародної безпеки, потребують суттєвого розвитку об'єднаних спроможностей. Особливе значення надається питанням налагодження взаємодії 3 міжнародними, регіональними і національними структурами 3 питань планування та проведення міжнародних операцій з підтримання миру i безпеки. Шляхи нарощування об'єднаних спроможностей визначаються Стратегічною концепцію "Активне залучення, сучасна оборона", прийнятою Лісабонським самітом у 2010 році. Відповідно до іiі положень, для оперативного планування операцій за межами зони відповідальності Альянсу застосовується “всеохоплюючий комплексний підхід”, який став розвитком “скоординованого підходу”.

Аналіз роботи багатонаціональних штабів миротворчих сил, штабу українопольско-литовскої миротворчої бригади УкрПолЛитБриг (UkrPolLitBrig), міжнародних навчань, підтверджує складнощі використання нових процедур оперативного планування. Вивчення та їх практичне використання $\epsilon$ важливим елементом підготовки офіцерів Збройних Сил України.

Аналіз основних досліджень i публікацій. Особливості оперативного планування за стандартами НАТО визначаються діючими стратегічними концепціями, положення яких $\epsilon$ основою оперативного планування. Процес і процедури оперативного планування та розвитку необхідних спроможностей викладені в Об'єднаній доктрині [1], Об'єднаній доктрині 3 планування операцій на оперативному рівні [2], Керівництві з проведення операцій [3],
Директиві щодо комплексного планування операцій [4]. Директива [4] визначає процес оперативного планування, регулює порядок підготовки, затвердження, імплементації та оцінювання оперативних планів і результатів їх виконання.

Значний вклад у роз'яснення і уточнення процедур планування був зроблений фахівцями Школи НАТО в Обераммергау, Німеччина. Національним університетом оборони України також розроблені методичні матеріалі 3 питань оперативного планування за стандартами НАТО, проведено низку спільних конференцій та семінарів.

Водночас, у вітчизняних фахових виданнях аналіз особливостей оперативного планування багатонаціональним штабом Об'єднаних сил миротворчих операцій 3 підтримання миру і безпеки, реагування на кризи i воєнні конфлікти не знайшов системного відображення.

Метою статті є визначення етапів i процедур оперативного планування міжнародних операцій 3 підтримання миру i безпеки (далі - операцій) на основі всеохоплюючого комплексного підходу.

Виклад основного матеріалу. Сучасні воєнні конфлікти характеризуються складними взаємними залежностями інформаційних, політичних, військових, соціальних, інфраструктурних, соціальних та економічних проблем, вирішення яких потребує послідовного і результативного застосування різних інструментів впливу.

Оперативне планування за стандартами НАTO визначається як діяльність багатонаціональних i національних органів управління всіх рівнів із розроблення системи політичних, інформаційних, військових та 
інших заходів в інтересах застосування до прийнятних умов (рівнів загроз) для збройних сил $з$ метою реагування на існуючі забезпечення міжнародного миру і стабільності або потенційні загрози, кризові ситуації та (рис. 1). воєнні конфлікти, переходу від неприйнятних

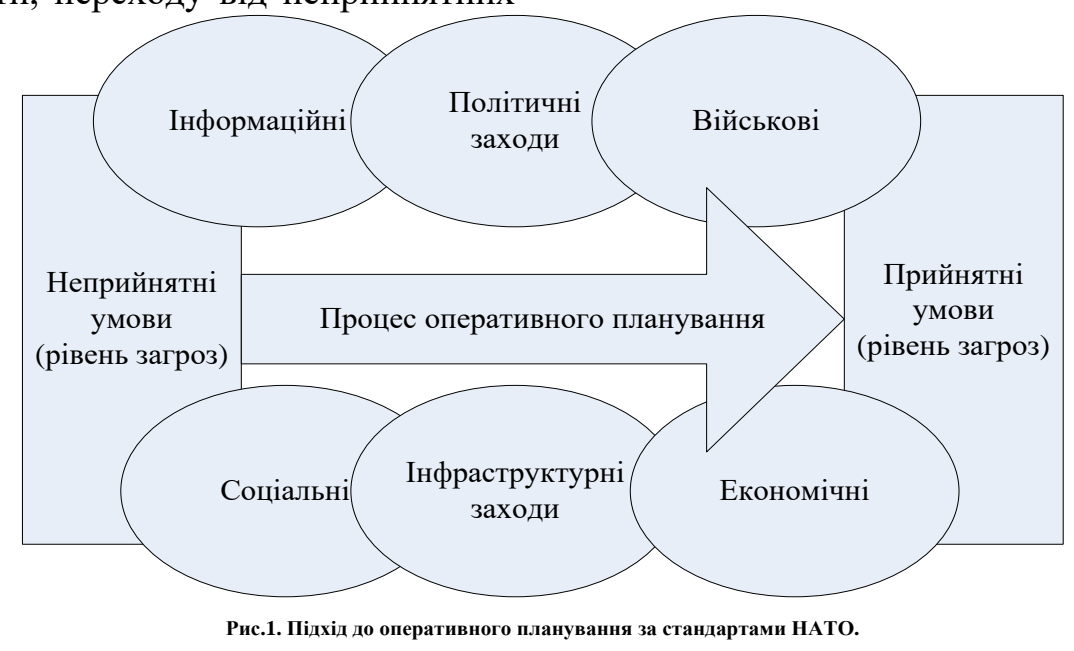

Зміна умов від неприйнятних до прийнятних потребує врахування зовнішніх чинників впливу, необхідних для досягнення запланованих цілей. Мета планування визначення послідовності дій у часі та просторі.

Оперативне планування здійснюється на рівнях:

стратегічному, під час розгортання i застосування збройних сил у рамках діючої Стратегічної концепції для досягнення політичних і воєнно-стратегічних цілей;

оперативному, на якому операції плануються i проводяться для досягнення стратегічних цілей на театрі або районах проведення операцій;

тактичному, на якому сили застосовуються для виконання завдань i досягнення воєнних цілей, що, зі свого боку, забезпечує успішне виконання завдань на оперативному і стратегічному рівнях.

У процесі оперативного планування визначаються порядок розроблення, координації, затвердження, виконання, перегляду, зміни і скасування плану операції; спільні зусилля на всіх рівнях; комплексне розуміння кризової ситуації; інші (крім суто військових) інструменти впливу, координація дій у часі.

Метою процесу $\epsilon$ розроблення планів досягнення необхідних кінцевих результатів і головного завдання (місіі), яке визначено мандатом на проведення операції.

Під час планування даються відповіді на такі питання: які умови мають бути досягнуті для виконання стратегічних $\mathrm{i}$ оперативних завдань операції з підтримання миру і безпеки? яка найсприятливіша послідовність дій для досягнення цих завдань? яким $\epsilon$ найоптимальніше використання спроможностей для здійснення цієї послідовності дій?

Процес оперативного планування передбачає:

всебічне оцінювання воєнно-політичної та стратегічної обстановки;

опис бойового простору (театру воєнних дій), тимчасових i інших параметрів i обмежень;

вибір результативного варіанта застосування сил у поєднанні 3 іншими (невоєнними) інструментами реагування на загрози;

детальне опрацювання обраного варіанта 3 урахуванням наявних спроможностей;

У рамках цього процесу розробляються, затверджуються, оцінюються під час реалізації і переглядаються або скасовуються оперативні плани всіх рівнів.

Основними принципами оперативного планування $\epsilon$ такі: логічність i обгрунтованість; всебічна оцінка обстановки; відкритість i порозуміння між усіма учасниками процесу планування; узгодженість; результативне використання ресурсів; гнучкість і адаптивність.

Багатонаціональними штабами здійснюється два види оперативного планування: завчасне планування; планування операцій реагування на кризи i воєнні конфлікти (безпосереднє планування).

Завчасне планування (Advance Planning) організовується на основі розвідувальних даних і оцінювання рівнів загроз безпеки та передбачає розроблення плануючих документів двох категорій: 
постійно діючих планів оборони (Standing Defence Plan);

планів дій в особливий період (Contingency Plan).

Постійно діючий план оборони розробляється в інтересах відбиття можливої агресії незалежно від географічного району. Планом визначаються заходи щодо відбиття повітряного (повітряно-космічного) нападу із залученням всіх наявних сил і засобів, порядок застосування чергових сил і органів управління та національних військових формувань, переданих у підпорядкування в мирний час, нарощування спроможностей багатонаціональних угруповань за рахунок перекидання i нарощування сил на обраних напрямках.

Плани дій в особливих умовах розробляються в інтересах забезпечення захисту від потенційних загроз і грунтується на розвідувальних даних i прогнозах розвитку обстановки у визначеному географічному районі. У разі прогнозованого переростання кризи у воєнний конфлікт план уточнюється відповідно до реальної ситуації. Такі плани передбачають введення в дію статті 5 Вашингтонського договору в обмежених географічних районах, які, за оцінкою розвідувальних органів, $\epsilon$ найбільш уразливими ділянками зони відповідальності.

Планування операції реагування на кризи і воєнні конфлікти (Crisis Response Planning) здійснюється відповідно до загально встановленого порядку кризового менеджменту. До того ж розробляється план операції в конкретному географічному районі в період наростання напруженості і виникнення загроз безпеці. Якщо кризова ситуація була спрогнозована заздалегідь, за основу задуму операції може бути взятий план дій в особливих умовах, 3 внесенням до нього відповідних змін залежно від розвитку обстановки. Під час раптового виникненні кризової ситуації задум операції розробляється на основі отриманих даних $i$ поточному розвитку обстановки.

Послідовність

роботи

багатонаціональних штабів, документи, що розробляються під час планування таких операцій, забезпечують циклічність процесу оперативного планування як за вертикаллю підпорядкованих штабів, так і за горизонталлю (оцінювання обстановки, прийняття рішення, виконання, оцінювання обстановки, прийняття рішення, перегляд плану, виконання тощо.

Процес оперативного планування починається 3 моменту отримання політико- військовим керівництвом відповідної розвідувальної інформації. На іï основі 3 врахуванням наявних спроможностей Генеральним секретарем приймається рішення на подальші дії, які доводяться у вигляді попередньої політико-військової директиви.

Підтримка прийняття рішення про вибір конкретного сценарію врегулювання кризи здійснюється безперервним відстеженням воєнно-політичної обстановки, яка відображається в документі "Стратегічна оцінка обстановки”. Оцінка включає пропозиції, розроблені профільними комітетами (військовий комітет, комітет 3 оборонної політики і планування, комітет 3 політичних аспектів операцій кризового врегулювання, комітет з економічної політики і партнерства, комітет з планування на випадок надзвичайних ситуацій).

Якщо обстановка потребує військового втручання багатонаціональних сил, ставиться завдання відповідним комітетам ініціювати розроблення варіантів реагування на кризу із залученням необхідних спільних воєнних i цивільних спроможностей. Багатонаціональні штаби на підставі отриманих попередніх розпоряджень розробляють варіанти застосування своїх військ (сил). Після затвердження визначеного варіанта реагування на кризову ситуацію видається попередню директиву про початок планування міжнародної операції 3 підтримання миру i безпеки.

У цьому документі викладаються стратегічні (політичні) цілі операції, кінцеві результати, визначаються головні та допоміжні завдання, а також політичні та інші обмеження. Крім того, надаються вказівки щодо розроблення задуму інформаційної операції, політики і технології інформування громадськості. Попередня директива $\epsilon$ підставою для багатонаціонального штабу на початок оперативного планування або інші дії.

Безпосередньо процес планування на стратегічному i оперативному рівнях складається з шести етапів (рис. 2).

Етап "Індикатори і раннє попередження" (Initiation) включає проведення попереднього оцінювання умов конфлікту (сторони, їх спроможності, географічні та погодні умови, населення, інфраструктура, обмеження тощо) та визначаються терміни підготовки до операції.

Результатом цього етапу $є$ : первинне оцінювання виникаючих криз (загальний опис кризи, індикатори), вказівки щодо заходів раннього попередження; заходи 3 підготовки 
до розгортання багатонаціонального штабу і запровадження консультацій 3 командуючим операцією; прогнозування розвитку ситуації (за необхідністю).
Етап "Оцінювання" (Orientation) включає оцінювання оперативної обстановки, визначення цілей операції та варіантів застосування воєнної сили.

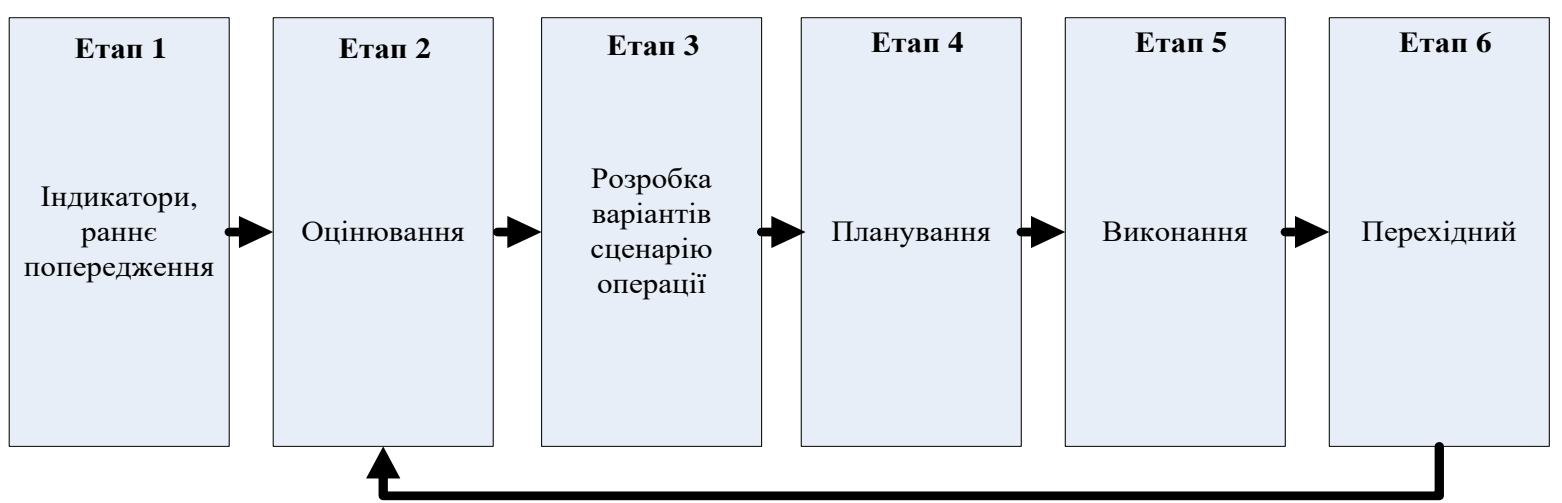

Рис. 2. Цикл оперативного планування.

Результатом етапу є: загроз; опис оперативної ситуації і потенційних

умови для початку міжнародної операції, проміжні стратегічні та воєнні цілі;

варіанти застосування Об’єднаних сил.
Оцінювання оперативної обстановки є під час операції. Оцінювання проводиться штабами всіх рівнів і включає вивчення безлічі об'єктивних і суб'єктивних факторів (рис. 2).

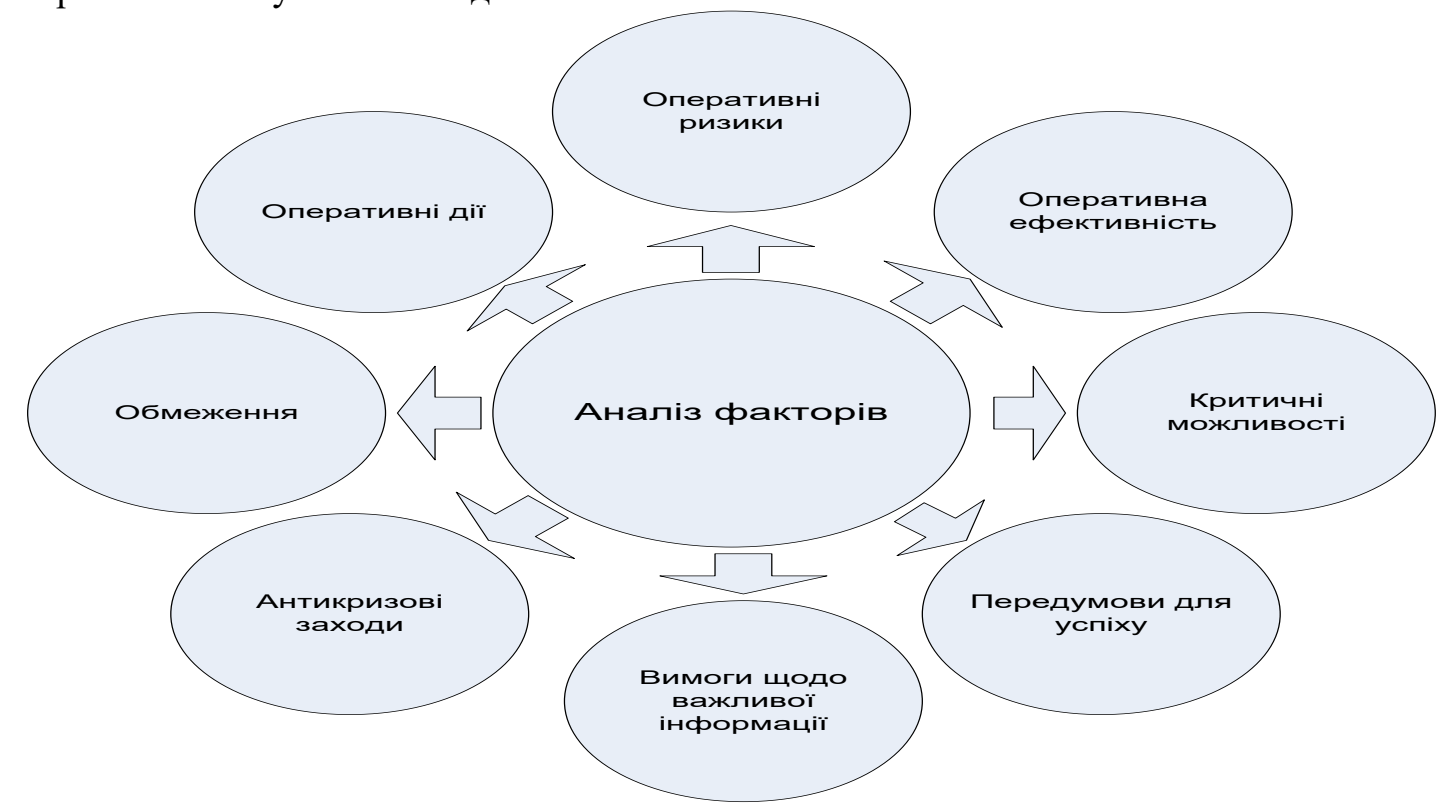

Рис. 3. Аналіз факторів при плануванні.

На етапі "Розроблення сценаріїв операції“" (Concept Development) проводяться:

планування застосування Об'єднаних сил; операційні розрахунки, які включають детальний аналіз операції (мета, цілі, завдання, терміни);

підготовка доповіді командуючому

Об'єднаними силами;

розроблення сценаріїв операції;

розроблення оперативних завдань;

проведення брифінгу з командирами.

Сценарії планування відображаються персоналом відділу J2 в системі комплексного операційного середовища (так звана “червона картина").

На етапі "Планування" (Plan Development) розробляється план операції, який також включає:

концепцію (задум) операції (цілі, необхідні спроможності);

план операції (OPLAN).

Багатонаціональний штаб розробляє задум операції, а потім і її план. До того ж на адресу підлеглих органів управління направляються директивні вказівки 3 організації планування на відповідному рівні. 
Командувач i командири всіх ступенів до об'єднання включно після отримання цих вказівок ініціюють процес оперативного планування в підлеглих штабах.

Після затвердження плану операції i віддачі наказу на приведення підпорядкованих сил і засобів у готовність до бойових дій проводяться заходи щодо передачі повноважень на управління і розгортання військ (сил).

Концепція операції має відповідати вимогам стратегічного операційного концепту (CONORS) та низці інших оперативних стандартів, відображати необхідні для досягнення цілей спроможності та засади їх застосування. OPLAN також відповідає вимогам CONORS i $\epsilon$ актуальним i результативним планом досягнення цілей операції та може включати низку допоміжних планів і додатків.

Задум операції $\epsilon$ основою плану, де визначається, як основні та допоміжні (забезпечення) формування різнорідного угруповання взаємодіятимуть для досягнення мети операції. Задум виробляється командувачем. До того ж критерієм його правильності будуть узгоджені дії підлеглих командирів, які не потребують втручання командувача. Задум операції включає в себе п'ять основних елементів: обстановка, завдання, виконання, всебічне забезпечення, управління.

Обстановка передбачає опис обставин, які призвели до необхідності розроблення задуму операції, з включенням відповідних подробиць щодо політичних цілей, обмежень і прогнозів розвитку обстановки.

Завдання - ясний і короткий опис цілей i характеру планованих дій, а також даних про місце і розрахунковий час проведення операції. Завдання має містити чітко сформульовані відповіді на питання: хто? (підлеглі сили і засоби), що? (якого результату мають досягти підлеглі війська), коли?/де? (відповідні просторові і тимчасові параметри) і навіщо? (цілі операції), формулювання завдання завжди має на увазі єдину мету, 3 якою має логічно випливати задум операції.

Виконання включає в себе бачення командувачем порядку i ходу виконання операції і включає:

вихідні дані - узагальнені дані про важливі особливості, виявлені під час 3'ясування завдання;

основи рішення і плану дій, включаючи опис військових цілей, умов закінчення військової операції і досягнення успіху. До того ж рішення командувача має бути сконцентровано на наданні загального впливу на війська супротивника i являти собою короткий i точний виклад послідовності досягнення оперативних цілей, що фактично пояснює дії своїх військ на тлі виконання плану вищого командування;

зміст етапів операції і характеру проведених заходів;

утримання військових i допоміжних цілей;

загальні вимоги до військ (сил);

вимоги щодо узгодження дій, що проводяться в рамках виконання інших операцій.

Всебічне забезпечення - опис вимог, необхідних для виконання бойового завдання, включаючи загальний виклад принципів роботи тилу, функціонування системи управління тилом, організації медичного, транспортного забезпечення, а також підтримання силами i засобами країни розміщення.

Управління. Виклад порядку підлеглості, функцій i повноважень, організації зв'язку і передачі управління через виведення 3 ладу того чи іншого пункту управління.

Після розроблення задуму штаб вдається до планування операції. До того ж визначається склад сил і засобів, необхідних для реалізації задуму, зокрема для всебічного забезпечення операції, а також узгоджуються тимчасові рамки розгортання військ (сил) на ТВД.

План операції являє собою детальний перелік реально здійсненних дій, який розробляється 3 урахуванням можливостей військових формувань, виділених країнамиучасницями для його реалізації. Він $\epsilon$ матеріальним втіленням теоретичних знань i досвіду командувача і його штабу. Наявність плану необхідно для досягнення взаєморозуміння командувача 3 його підлеглими, а також для доведення до них максимально повної інформації під час управління військами (силами).

Типовий план операції включає ті ж п'ять розділів, що і задум. Додатки до плану операції суттєво доповнюють, конкретизують і роз'яснюють його. Типовий перелік містить 40 обов'язкових додатків.

На етапі "Виконання" (Plan Review) планування передається від відділу J5 "Планування" до відділу J3 "Операції" багатонаціонального штабу. На цьому етапі проводиться оцінювання та корегування поточного плану. Оцінюванню підлягають оперативні плани та дії на короткий термін, а 
корегуванню, за необхідності, довгострокові плани.

Спираючись на підготовлені документи, командир об'єднаних сил організує виконання плану за допомогою надання бойових розпоряджень (FRAGO) або розпорядження на початок нового циклу оперативного планування.

Етап

"Перехідний"

частково перекривається 3 п’ятим етапом. Цілями $\epsilon$ проведення нового оперативного оцінювання та переходу до нового циклу планування. Основна увага приділяється виходу 3 операційної зони без створення вакууму влади i умов для подальшого розвитку конфлікту.

Оперативне планування триває протягом всієї операції. Цей процес не можна вважати завершеним в його первісному варіанті, він коригується та адаптується до обстановки. Перегляд та доопрацювання - це ключові аспекти безперервно триваючого процесу оперативного планування, здійснюваного у разі зміни ситуації або в міру того, як змінюється розуміння обстановки командувачем. Перегляд, який $\epsilon$ скоріше правилом, ніж винятком, передбачає оцінювання обстановки, що змінилася, а за необхідності й коригування сформульованих раніше умов (критеріїв) успішного завершення воєнної операції.
Особливості оперативного планування багатонаціонального штабу полягають в основному в застосуванні англосаксонської моделі прийняття рішень. Для правильного розуміння змісту оперативних документів необхідно знати сутність застосовуваних в них понять, таких як:

оперативна ідея - продукт розумової діяльності командувача (штабу), який розробляється в процесі творчого пошуку вирішення різних проблем, є основою для розроблення задуму командувача, а надалі замислу операції;

оперативний дизайн - процес висунення і коригування оперативних ідей, включає три основних елементи: оцінка оперативної обстановки; визначення найважливіших показників майбутньої операції для формування ऑii задуму (концепціï), розроблення плану операції.

Цей процес потребує унікального поєднання мислення, досвіду та інтуїції, не допускає надмірної замкнутості виключно на командирі. Командиру насамперед потрібно чітко сформулювати бажані (кінцеві) результати міжнародної операції, необхідні спроможності для іiі успішного завершення, а також особливості, які враховуються в процесі оперативного планування (рис. 4).

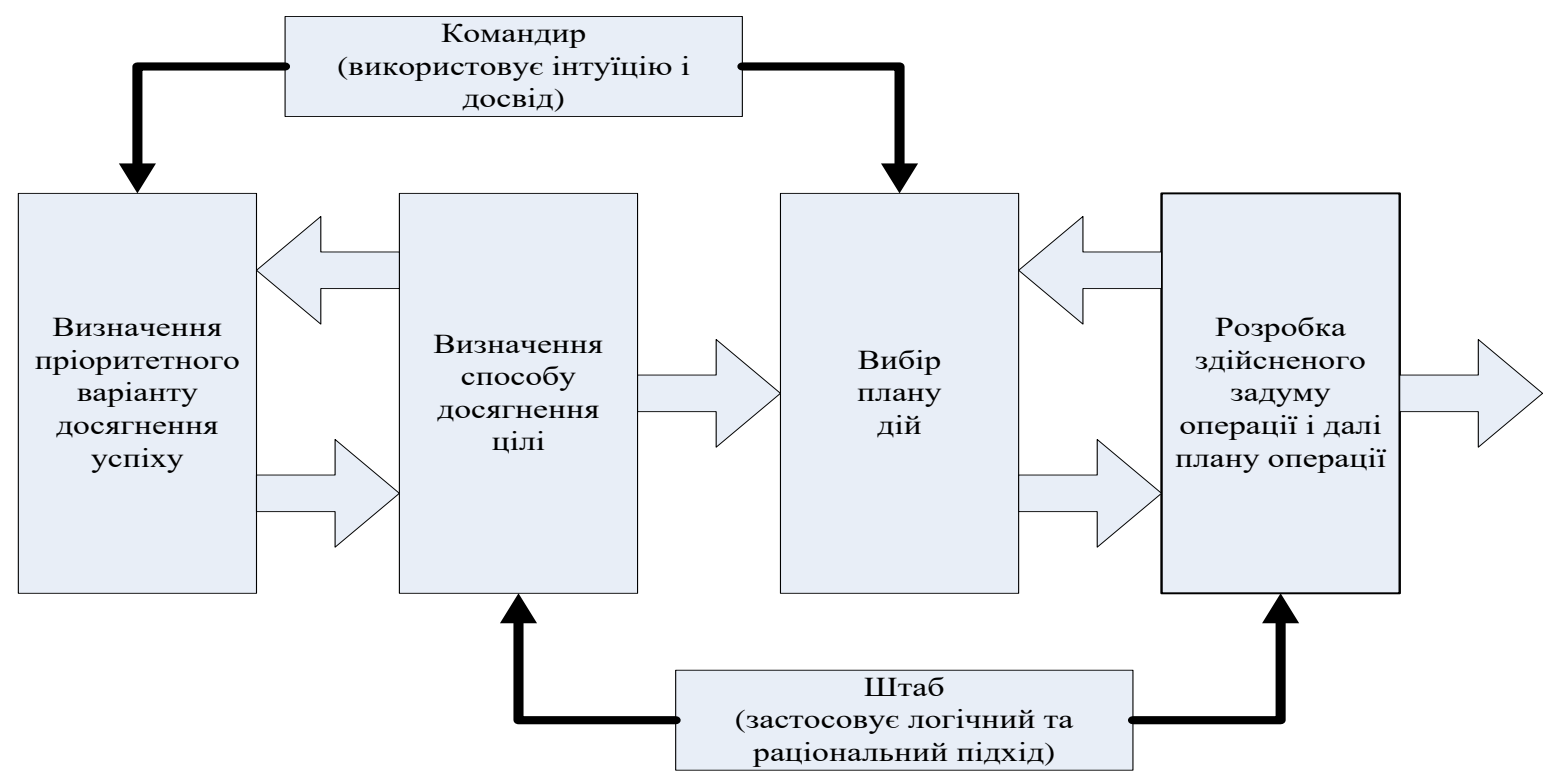

Рис. 4. Послідовність роботи багатонаціонального штабу в процесі оперативного планування.

3 огляду на це, оперативне планування найрезультативнішого варіанта досягнення багатонаціонального штабу розглядається як цілей операції. Виконуючи конкретні вказівки $\mathrm{i}$ процес розроблення і вдосконалення оперативних чітко розуміючи задум командира, ідей, найважливішим, але не кінцевим, багатонаціональний штаб деталізує його результатом якого $є$ затверджений план операції варіант і розробляє план операції.

(дій в особливих умовах). До того ж командир

Об'єднаних сил зосереджується на пошуку

Визначення та оцінювання основних показників операції, що планується, 
підготовка концепції (задуму) операції, здійснюються 3 використанням елементів оперативного дизайну (Operational Design Concept). Вони направлені на досягнення трьох цілей:

зосередження уваги на найбільш важливих питаннях у процесі оцінювання обстановки;

опису в планах i директивах доступною для розуміння мовою, якого результату і як потрібно його досягти;

правильної оцінки ходу воєнної операції.

У наш час у процесі оперативного планування НАТО використовуються 15 концептів оперативного дизайну.

1. Очікуваний результат/мета операції являє собою сукупність критеріїв і показників, які характеризують ВПО, стан об'єднаних військ (сил) i сил противника на момент успішного завершення операції. Варіанти прийнятних воєнних i політичних умов, необхідних для завершення операції, визначаються перед початком бойових дій. Для розроблення реального і результативного плану важливо чітке розуміння цих умов, без чого не можна забезпечити зосередження зусиль. Усі дії Альянсу потрібно розглядати як внесок у досягнення очікуваного результату/цілі операції.

2. Завдання. В інтересах отримання очікуваного результату багатонаціональним силам ставляться конкретні, чітко сформульовані завдання. Під час спільних операцій командувачі (командири) організовують взаємодію 3 цивільними структурами.

3. Основні елементи спроможностей - це ключові фактори, що визначають боєздатність протиборчих сторін. Крім того, їх можна розглядати як сукупність характеристик i спроможностей військ (сил), а також особливостей місцевості, які дають змогу захопити ініціативу, отримати перевагу в співвідношенні сил і засобів або в моральнопсихологічній сфері. Придушення або нейтралізація основних елементів потенціалу противника сприяє досягненню поставлених цілей. Крім виявлення основних складових носіїв спроможностей противника, не менш важливо визначити власні спроможності, провести оцінювання їх уразливості та забезпечення захисту. Первинний їх аналіз потребує безперервного коригування у процесі планування і проведення операції.

4. Ефект являє собою результат однієї або кількох дій, який впливає на матеріальний або поведінковий стан системи (елементів системи) i сприяє досягненню одного або більше критичних пунктів (вирішальних умов).

5. Критичний пункт - це точка в часі, в просторі або інформаційному середовищі, від якої залежить можливість ефективного використання основних елементів потенціалу як свого, так і противника.

6. Вирішальна умова - це поєднання обставин, подій чи явищ, ефект від яких дає змогу отримати значну перевагу над противником або внести істотний внесок у досягнення цілей операції. Така умова визначається в процесі вивчення основних елементів потенціалу противника, a їх створення відбувається в процесі скоординованих дій різних структур, часто розділених у часі та просторі.

7. Варіант проведення операції - одна 3 можливих комбінацій впливу на основні елементи потенціалу під час операції шляхом забезпечення вирішальних умов у часі та просторі. Варіанти проведення операції утворюють взаємозв'язки (не обов'язково послідовні в часі та просторі) між вирішенням завдань щодо впливу на ті чи інші вирішальні пункти (досягненням тих чи інших вирішальних умов) i відповідним станом основних елементів потенціалу. Зосереджуючи увагу на досягненні очікуваного результату/мети операції, командувачі вибирають ті чи інші варіанти проведення операції для найефективнішого використання наявних сил і засобів у всіх просторових і часовому вимірах.

8. Встановлення послідовності дій у рамках військової операції або кампанії являє собою механізм реалізації певних заходів для досягнення більшої вірогідності успіху в придушенні або нейтралізації основних елементів потенціалу противника. Як правило, в рамках операції ефективніше здійснювати одночасні різноманітні дії всіх елементів угруповання, спрямовані на досягнення єдиного результату, що пригнічує здатність противника до опору. Як тільки буде визначена повна послідовність дій, командувач може прийняти рішення про поділ військової операції на відповідні етапи.

9. Етапи операції. Мета поділу військової операції на етапи полягає в забезпеченні безперервності та високого темпу дій, щоб уникнути непотрібних оперативних пауз. Ці етапи виконуються послідовно (початок чергового залежить від успішного завершення попереднього), але можуть також накладатися один на одного, 
що найхарактерніше для миротворчих операцій.

10. Планування дій в особливих умовах. Для кожної скоєної дії існує певний діапазон можливих наслідків, які можуть створювати умови, необхідні для досягнення (або перешкоджати досягненню) очікуваного результату/мети операції. Наслідки, які виявилися сприятливішими, ніж прогнозувалося, можуть використовуватися для подальшого розвитку успіху, в іншому разі не виключено виникнення ризиків, які потребують певних дій для їх нейтралізації. До того ж успіх операції залежить, по-перше, від здатності передбачення наслідків, а по-друге, від попереднього розроблення можливих варіантів дій через той чи інший результат.

11. Кульмінаційний момент (межа спроможностей) може наступити під час як оборонних, так і наступальних дій. У процесі настання він означає, що бойовий потенціал наступаючих військ (сил) вже не вище, ніж у тих, що обороняються, внаслідок чого перші повинні будуть перейти до оборони, інакше існує ризик ураження в разі контрнаступу противника. Досягнення обороняються військами (силами) кульмінації означає, що вони більш не мають можливості вживати контрнаступаючої дії або успішно оборонятися і у разі загрози поразки змушені відступати або виводити війська 3 бою. Правильна ідентифікація кульмінаційного моменту дає змогу розвинути успіх дій або уникнути негативних наслідків за допомогою планування оперативних пауз. Послідовність дій та розподіл операції на етапи мають забезпечити впевненість у тому, що дії військ (сил) противника досягли кульмінації раніше, ніж своїх цілей, а дії своїх військ (сил) досягли мети задовго до цього моменту.

12. Оперативна пауза це тимчасове припинення бойових дій під час операції, щоб уникнути ризику виникнення кульмінаційного моменту, а також для відновлення боєздатності військ (сил), які братимуть участь у наступному етапі операції. Оскільки бойові дії не можуть вестися безперервно, виникає необхідність у періодичних паузах, тим часом як ініціатива дій зберігатиметься через використання інших способів впливу, можливо, в іншому оперативному середовищі. Іноді потрібно робити паузу в рамках одного напрямку дій для концентрації зусиль на іншому.

13. Завершення чергового етапу дій i перехідний процес. Термін “завершення” у цьому контексті означає перехід до наступної формі дій, а не припинення військових дій i “проведення парадів перемоги”. Замість цього командувач військами (силами) прагне зосередитися на тому, що станеться після досягнення кінцевих цілей військової операції і як зберегти вже досягнутий успіх на тривалий термін. Оскільки військові цілі можуть бути досягнуті задовго до стратегічних цілей операції (головним чином під час проведення миротворчих операцій), може знадобитися використання військової сили після закінчення бойових дій.

14. Прямий і непрямий підходи. Якщо знищення (нейтралізація) основних елементів потенціалу противника можливо у разі прямої атаки, то це доцільніше, ніж проведення цілої серії дій зі створення вирішальних умов $\mathrm{i}$ впливу на критичні пункти.

Існує два альтернативних підходи до впливу на основні елементи потенціалу противника:

прямий підхід - послідовний (одночасний) безперервний вплив на основні елементи потенціалу противника 3 метою поразки сил протилежної сторони, забезпечення захисту основних елементів своїх спроможностей, застосовується в разі наявності явної переваги над військами (силами) противника, а ризик за такої умови $\epsilon$ допустимим;

непрямий підхід - використання слабких сторін противника (як фізичних, так i моральних) при одночасному уникненні прямого зіткнення з основними його силами, застосовується у разі явного недоліку своїх сил і засобів для здійснення прямого впливу на основні елементи потенціалу противника або коли ризик $є$ неприйнятним.

15. Критерії успіху. Для кожної конкретної мети командувач військами (силами) встановлює критерії її досягнення піддаються вимірюванню наочні показники щодо вирішальних умов або ефектів.

Загалом елементи оперативного дизайну можна розглядати як інструмент, за допомогою якого командир, спираючись на всебічну оцінку обстановки, особистий досвід і інтуїцію, маючи чіткі цілі та знаючи свої можливості, формулює задум майбутньої операції.

На всіх етапах оперативного планування багатонаціональним штабом забезпечується:

формування головного завдання (місіі); визначення бажаних кінцевих результатів операції та критеріїв успіху; визначення "центрів ваги”; єдність командування і Об'єднаних сил; єдність зусиль сил; 
гнучкість дій (можливість швидкого корегування плану операції у разі зміни обстановки);

бойова стійкість сил;

доведення плану до підлеглих підрозділів (сил).

оцінювання ризиків, що очікуються;

проведення до єдиного стандарту процесу оперативного планування та відповідних процедур обміну інформацією національними військовими контингентами;

переведення стратегічних політичних цілей у військові цілі стратегічного, оперативного та тактичного рівнів;

взаємодія та спільна робота штабів усіх рівнів;

процес логічного доведення і реалізації вказівок керівництва операцією та розроблення реальних варіантів завдань і дій, направлених на досягнення очікуваного кінцевого результату;

поліпшення можливості командира щодо керування та доведення планів до завершального етапу;

прискорення логічної та творчої роботи штабу, процесів прийняття рішення командиром у неясних і невизначених умовах обстановки, коли час і наявна інформація не задовольняють потребам;

надання командирам можливості

узгоджувати та поєднувати зусилля неоднакових національних підрозділів i командувань під час плануванні операцій;

оцінювання кінцевих результати процесу планування.

Планування операцій орієнтовано на досягнення військових і невійськових цілей, які визначаються воєнно-політичним керівництвом під час політичних і ресурсних обмежень.

Головним у процесі планування $\epsilon$ командир. Вказівки командира на кожному рівні забезпечують багатонаціональний штаб баченням того, яким чином має виконуватись поставлена задача, як забезпечувати підлеглим свободу дій в більш широкому контексті завдання.

3 досвіду навчань, розроблення плану міжнародної операції 3 підтримання миру i безпеки потребує до 30 діб, всебічне оцінювання обстановки і підготовка документа “Стратегічна оцінка обстановки" потребує до 7 діб, розроблення та затвердження варіантів залучення багатонаціональних сил i стратегічної директиви за порядком планування - 3 доби.

Висновки. Загалом досвід успішного проведення країнами НАТО коаліційних воєнних операцій за останні 25 років показує, що система прийняття рішень i порядок оперативного планування, прийняті в Північноатлантичному Альянсі, відповідають сучасним вимогам щодо досягненню військово-політичних і стратегічних цілей із залученням оптимального складу сил i засобів.

Для цього розроблено і підтримується гнучкий процес оперативного планування операцій $з$ реагування на збройні конфлікти, який передбачає всеохоплюючий підхід, чіткий порядок прийняття рішень, планування операцій та цивільно-військових місій, створення необхідних спроможностей для досягнення поставлених цілей. Такий механізм дає змогу оперативно та результативно протидіяти сучасним викликам та загрозам із залученням тільки необхідних спроможностей.

Всеохоплюючий підхід до планування операцій реагування на кризові ситуації - це прояв системного підходу до оперативного планування i безпосереднього проведення операції, як невід'ємних частин комплексного підходу к забезпеченню воєнної безпеки загалом. Особливості підходу визначаються комплексним застосуванням міжвидових формувань збройних сил різних країн, необхідністю координації бойового застосування різнорідних сил 3 метою досягнення максимально результативного використання спільних спроможностей, залученням невоєнних засобів впливу та цивільних структур різного рівня к процесу врегулювання конфлікту.

Напрями подальших досліджень направлені на аналіз взаємозв'язків і спільних процедур оперативного i оборонного планування за стандартами НАТО.

\section{СПИСОК ВИКОРИСТАНОЇ ЛІТЕРАТУРИ}

1. Allied Joint Doctrine, AJP 01D, ed. 2017. URL: https://assets.publishing.service.gov.uk/ government/ uploads/system/uploads/attachment_data/file/60222 5/doctrine_nato_allied_joint_doctrine_ajp_01.pdf.

2. Allied Joint Doctrine for operational level planning, AJP-5, ratification draft). URL: https://assets.publishing. service.gov.uk/government/ uploads/system/uploads/attachment_data/file/78726 3/

archive_doctrine_nato_op_planning_ajp_5_with_U K_elements.pdf.

3. Conduct of the operational, AJP 3B, ed. 2011. URL: $\quad$ http://everyspec.com/nato/nato-atp/ajp3b_mar2011_50361. 
4. COPD, Comprehensive Operations Planning Directive https:/www.act.nato.int/images/stories/events/2016 interim version 2.0 ed. 2013. URL: / sfpdpe/copd_v20_summary.pdf.

Стаття надійшла до редакційної колегії 05.11.2019

Павликовский А. К., канд. воен. наук, доцент;

Иващенко А. М., канд. техн. наук, доцент

Возняк С. Н., канд. техн. наук, ст. науч. сотр.

Центр военно-стратегических исследований Национального университета обороны Украины имени Ивана Черняховского, Киев

Особенности оперативного планирования многонациональным штабом Объединенных сил НАТО международных операций по поддержанию мира и безопасности

Резюме. Рассматриваются изменения в системе оперативного планирования НАТО, которые были введены после саммитов Североатлантического Альянса 2010 - 2018 гг., этапы планирования, задачи и разрабатываемые оперативные документы.

Ключевые слова: НАТО; штаб Объединенных сил; оперативное планирование; этапы; задачи.

A. Pavlikovskij, PhD (Military), associate professor;

A. Ivashchenko, PhD (Technical), associate professor;

S. Vozniak, PhD (Technical), senior researcher

Center for Military and Strategic Studies of the National Defence University of Ukraine named after Ivan Cherniakhovskyi, Kyiv

Special aspects of the Operational Planning by NATO Multinational Headquarters for the International Peace and Security Operations

Resume. Changes in NATO's operational planning system introduced after the 2010-2018 NATO summits, planning stages, tasks and operational documents under development are reviewed.

Keywords: NATO; joint force headquarters; operational planning; stages; tasks. 